CLINICAL STUDY

\title{
Preoperative diagnosis of insulinoma: low body mass index, young age, and female gender are associated with negative imaging by endoscopic ultrasound
}

\author{
P H Kann ${ }^{1,3}$, D Ivan ${ }^{1}$, A Pfützner ${ }^{3}$, Th Forst ${ }^{3}$, P Langer ${ }^{2}$ and S Schaefer ${ }^{1}$ \\ ${ }^{1}$ Division of Endocrinology and Diabetology and ${ }^{2}$ Department of Surgery, Philipps University Hospital, D-35033 Marburg, Germany and ${ }^{3}$ Institute for \\ Clinical Research and Development, 55118 Mainz, Germany
}

(Correspondence should be addressed to P H Kann; Email: kannp@med.uni-marburg.de)

\begin{abstract}
Objective: Endoscopic ultrasound (EUS) is a highly reliable procedure to localize insulinomas preoperatively. It has been considered to be important in planning surgical strategy, especially considering a minimal invasive approach. However, even under ideal conditions experienced examiners miss about $10-20 \%$ of insulinomas by EUS imaging.

Design and methods: This retrospective study aimed to identify factors associated with negative EUS imaging. Twenty-nine consecutive patients (24 benign and 5 malignant) with sporadic pancreatic insulinomas confirmed by successful surgery and positive histopathology were included. All EUS examinations were performed by one single experienced examiner over a period of one decade.

Results: Three of the tumors were not detected by preoperative EUS as they were isoechoic to the surrounding healthy pancreatic tissue; 25 could be detected as hypoechoic lesions, (including all malignant tumors), and one lesion was hyperechoic. Low body mass index $(P=0.053)$ and young age $(P=0.037)$ were associated with negative EUS imaging. All patients with negative imaging were females. The position on the examiner's learning curve, the diameter and location of insulinoma, and endocrine parameters (insulin concentrations and insulin-glucose ratios in the prolonged fasting test) had no influence on the success of EUS imaging.

Conclusions: Some insulinomas are missed by preoperative EUS imaging as they are completely isoechoic. A low body mass index, female gender, and young age might be risk factors for negative imaging.
\end{abstract}

European Journal of Endocrinology 157 209-213

\section{Introduction}

The diagnostic procedure in cases of suspected insulinoma is based on standard endocrine test procedures, especially prolonged fasting test (1-3). Imaging procedures are a second-line tool when the diagnosis of insulinoma has been established, and are used to localize the source of pathologic insulin secretion. Endoscopic ultrasound (EUS) has been shown to be highly accurate in the preoperative localization of insulinomas (4-8). It has been considered to be important in planning surgical strategy, especially considering a minimal invasive approach (7-9).

However, EUS imaging is unable to detect and localize about 10-20\% of insulinomas, even if EUS is performed under ideal conditions by very experienced examiners $(8,10)$.

This retrospective study aimed to identify factors associated with negative EUS imaging in patients with sporadic pancreatic insulinoma confirmed by successful surgery and positive histopathology, allowing evaluation of preoperative localization by EUS.

\section{Materials and methods}

In this retrospective study, 29 consecutive patients (12 males and 17 females) admitted to the University Hospital of Mainz, Germany from 1997 to 2002 and to the University Hospital of Marburg, Germany from 2002 to 2007 because of sporadic insulinoma, fulfilling the following criteria, could be included:

An attempt at preoperative localization of insulinoma by EUS imaging performed by one single experienced examiner (PH Kann), successful surgery and positive histopathology with evaluation of preoperative EUS findings. 
Patients with multiple endocrine neoplasia were not included in this study.

EUS was performed using a Pentax FG 32 UA endosonoscope with a longitudinal $7.5 \mathrm{MHz}$ sector array in combination with a Hitachi EUB 420 or 525 ultrasound computer. The pancreatic body and tail were imaged from the stomach, the pancreatic head, and the processus uncinatus from the antrum, the duodenal bulb, the descending and the horizontal part of the duodenum. Contrary to the usual procedure of numerous examiners investigating patients lying on the left side, patients were in supine position to prevent the transducer from slipping over the pancreas to a more lateral position (8). Premedication was performed with pentazocine, diazepam, and atropine. Examination time was $\sim 45$ min.

For each patient, the following items were evaluated from the patient record and/or EUS report and/or by personal contact and/or by information of the patient's general practitioner:

- number of examinations (i.e. position in the examiners 'learning curve')

- gender (male/female)

- age (years)

- body mass index $\left(\mathrm{kg} / \mathrm{m}^{2}\right)$

- largest tumor diameter (mm, taken from preoperative EUS imaging, if negative from the report of histopathology)

- benignancy/malignancy

- highest absolute insulin serum concentration $(\mu \mathrm{U} / \mathrm{ml})$ during episodes of hypoglycemia in the prolonged fasting test

- highest ratio: insulin serum concentration $(\mu \mathrm{U} / \mathrm{ml}) /$ blood glucose $(\mathrm{mg} / \mathrm{dl})$ in the prolonged fasting test

- echogeneity of the tumor (hypo-/iso-/hyperechoic).

Statistical analysis was calculated using SPSS 12.5 software (SPSS Inc., Chicago, IL, USA) by $t$-test for independent samples. Statistical significance level: $P<0.05$ was considered significant.

\section{Results}

Patients' characteristics and results of data collection are displayed in Table 1.

Twenty-six of 29 pancreatic insulinomas (90\%) were detected by EUS imaging. Twenty-five insulinomas were characterized as a hypoechoic lesion, either completely or in part, then mainly showing a hypoechoic bordering zone (halo; group 1; see Fig. 1). Fourteen were located in the pancreatic head/processus uncinatus, six in the corpus, and five in the tail. All malignant tumors were in this group. Three insulinomas could not be detected by preoperative EUS imaging as they were isoechoic to the surrounding healthy pancreatic tissue (group 2). Two were located in the pancreatic corpus and one in the tail. Even by intraoperative ultrasound they could only be detected following palpation of the pancreas (see Fig. 2). One insulinoma was characterized as a hyperechoic lesion (see Fig. 3). This particular insulinoma was located in the pancreatic tail and not included in further statistical analysis.

Comparing group 1 (positive imaging, hypoechoic) and group 2 (negative imaging), a low body mass index $\left(28.8 \pm 6.8\right.$ vs $\left.20.7 \pm 1.6 \mathrm{~kg} / \mathrm{m}^{2} ; P=0.053\right)$ strongly tended to be associated with negative imaging. In one patient with a detected hypoechoic insulinoma, the body mass index could not be evaluated any more. Young age too $(48.5 \pm 15.1$ vs $28.7 \pm 10.5$ years; $P=0.037)$ was associated with negative imaging. All patients with negative imaging were females (see Fig. 4).

The maximum tumor diameter was not different between both groups $(20.2 \pm 14.1$ vs $10.5 \pm 6.4 \mathrm{~mm}$; $P=0.351)$. In one case of isoechoic insulinoma, the histopathology report did not mention the tumor diameter.

The diagnosis of insulinoma had been given after positive endocrine testing: in 25 patients at least one prolonged fasting test was performed. Data of one of these patients included only insulin-glucose ratios but no absolute glucose or insulin concentrations; data of one further patient were not available any more. In four patients no prolonged fasting test was performed because of poor clinical condition and typical symptoms (all with malignant insulinoma).

Prolonged fasting revealed a pathologic insulinglucose ratio $>0.25$ (11) in all but one patient. In this particular patient, the maximum insulin-glucose ratio was 0.08. Pathologic serum insulin concentrations > $6 \mu \mathrm{U} / \mathrm{ml}$ during episodes of hypoglycemia (venous glucose concentration $\leq 45 \mathrm{mg} / \mathrm{dl}, 2.5 \mathrm{mmol} / \mathrm{l})(1,3)$ were seen in all but two patients. The lowest glucose concentration in one of these particular patients was $50 \mathrm{mg} / \mathrm{dl}(2.8 \mathrm{mmol} / \mathrm{l}$, insulin $21.8 \mu \mathrm{U} / \mathrm{ml})$, in one further patient the maximum serum insulin concentration was $3.33 \mu \mathrm{U} / \mathrm{ml}$. Maximum serum insulin concentration during episodes of hypoglycemia $(38.1 \pm 39.9$ vs $27.9 \pm 16.6 \mu \mathrm{U} / \mathrm{ml} ; P=0.670)$ and maximum insulin-glucose ratio $(1.1 \pm 1.3$ vs $0.8 \pm$ $0.5 \mu \mathrm{U} / \mathrm{ml}$ per $\mathrm{mg} / \mathrm{dl} ; P=0.725)$ were not different between the groups.

The insulinomas missed by EUS were on positions 18 , 23 , and 24 on the examiners 'learning curve'.

\section{Discussion}

Insulinomas are not very frequent. In most cases they are singular, pancreatic, benign tumors, and occur sporadically; however, they may occur as manifestation of multiple endocrine neoplasia type 1 (12). Several test procedures for the diagnosis of insulinoma are available, the most important being the in-hospital monitored $72 \mathrm{~h}$ 
Table 1 Patients' characteristics.

\begin{tabular}{|c|c|c|c|c|c|c|c|c|c|c|c|}
\hline Number & $\begin{array}{l}\text { Date } \\
\text { EUS }\end{array}$ & Gender & $\begin{array}{c}\text { Age } \\
\text { (years) }\end{array}$ & BMI & $\begin{array}{c}\text { Tumor } \\
\text { diameter } \\
(\mathrm{mm})\end{array}$ & Histology & $\begin{array}{l}\text { Insulin } \\
(\mu \mathrm{U} / \mathrm{ml})\end{array}$ & $\begin{array}{c}\text { Insulin- } \\
\text { glucose } \\
\text { ratio } \\
(\mu \mathrm{U} / \mathrm{ml} \\
\mathrm{per} \\
\mathrm{mg} / \mathrm{dl})\end{array}$ & $\begin{array}{l}\text { Echo- } \\
\text { geneity }\end{array}$ & Detection & Location \\
\hline 1 & $01 / 97$ & Female & 74 & 26.04 & 13 & Benign & 45 & 1.23 & Нуро & Yes & Caput \\
\hline 2 & $05 / 97$ & Female & 55 & 28.63 & 15 & Benign & & & Нуро & Yes & Tail \\
\hline 3 & $06 / 97$ & Male & 37 & 30.10 & 10 & Benign & 30 & 0.83 & Нуро & Yes & Caput \\
\hline 4 & $07 / 97$ & Male & 56 & 31.55 & 19 & Benign & 95.8 & 2.66 & Hypo & Yes & Tail \\
\hline 5 & 08/97 & Male & 48 & 29.39 & 14 & Benign & 17.1 & 0.63 & Нуро & Yes & Corpus \\
\hline 6 & $04 / 98$ & Male & 62 & 28.08 & 52 & Malignant & & & Нуро & Yes & Caput \\
\hline 7 & $11 / 98$ & Female & 54 & & 70 & Malignant & & & Нypo & Yes & Tail \\
\hline 8 & $12 / 98$ & Female & 67 & 25.49 & 10 & Benign & 26.8 & 0.93 & Нуро & Yes & Caput \\
\hline 9 & 08/99 & Male & 50 & 22.55 & 19 & Malignant & & & Нуро & Yes & Caput \\
\hline 10 & 08/99 & Female & 42 & 19.71 & 37 & Malignant & & & Нуро & Yes & Caput \\
\hline 11 & $10 / 00$ & Female & 17 & 22.34 & 13 & Benign & & 0.70 & Нypo & Yes & Caput \\
\hline 12 & $12 / 00$ & Female & 67 & 33.98 & 13.5 & Benign & 22 & 0.56 & Нypo & Yes & Corpus \\
\hline 13 & 07/01 & Male & 58 & 26.29 & 13 & Benign & 13.1 & 0.44 & Нуро & Yes & Caput \\
\hline 14 & $11 / 01$ & Female & 33 & 21.58 & 9 & Benign & 21.8 & 0.44 & Нуро & Yes & Caput \\
\hline 15 & 06/02 & Male & 63 & 31.35 & 20 & Benign & 16 & 0.53 & Нуро & Yes & Caput \\
\hline 16 & $12 / 03$ & Female & 47 & 26.76 & 29 & Malignant & 176.2 & 5.87 & Нуро & Yes & Tail \\
\hline 17 & $12 / 03$ & Male & 15 & 28.05 & 16 & Benign & 51 & 1.46 & Нуро & Yes & Tail \\
\hline 18 & $09 / 04$ & Female & 29 & 20.43 & & Benign & 10.4 & 0.35 & Iso & No & Corpus \\
\hline 19 & 09/04 & Male & 50 & 26.00 & 11 & Benign & 18.37 & 0.48 & Нуро & Yes & Corpus \\
\hline 20 & $10 / 04$ & Male & 32 & 46.24 & 26 & Benign & 49.2 & 1.14 & Нуро & Yes & Caput \\
\hline 21 & $11 / 04$ & Female & 61 & 26.02 & 12.4 & Benign & 9.5 & 0.26 & Нуро & Yes & Corpus \\
\hline 22 & $12 / 04$ & Female & 48 & 23.42 & 13 & Benign & 12.74 & 0.45 & Нуро & Yes & Caput \\
\hline 23 & $12 / 04$ & Female & 39 & 19.26 & 6 & Benign & 43.4 & 1.24 & Iso & No & Corpus \\
\hline 24 & $02 / 05$ & Female & 18 & 22.43 & 15 & Benign & 29.8 & 0.88 & Iso & No & Tail \\
\hline 25 & $05 / 05$ & Female & 27 & 30.12 & 20 & Benign & 30.4 & 0.87 & Hypo & Yes & Caput \\
\hline 26 & $10 / 05$ & Male & 55 & 37.33 & 15.4 & Benign & 28.3 & 0.75 & Нуро & Yes & Caput \\
\hline 27 & $03 / 06$ & Female & 29 & 21.05 & 24 & Benign & 122. 7 & 4.23 & Hyper & Yes & Tail \\
\hline 28 & $02 / 07$ & Male & 42 & 23.70 & 12.3 & Benign & 3.33 & 0.08 & Нуро & Yes & Corpus \\
\hline 29 & $02 / 07$ & Female & 53 & 46.45 & 22.6 & Benign & 58.1 & 1.49 & Нуро & Yes & Corpus \\
\hline
\end{tabular}

Empty spaces, data not obtained or not available.

fasting test, with a diagnostic sensitivity and specificity of nearly $100 \%$ (1-3). A fasting test of $48 \mathrm{~h}$ has been proposed (13), but this test duration remains controversial (2).

After diagnosis, localization of insulinomas may be performed by abdominal ultrasound, computed tomography, magnetic resonance imaging, or somatostatin receptor scintigraphy. However, only low sensitivities have been shown in different studies $(4-8,14)$. EUS imaging has been shown to be very effective for the preoperative localization of insulinomas and has been suggested as first-line investigation $(4,15-17)$. The largest cohort published (7) refers to 40 patients and comes to the worst results available in the literature, with correct localization in $65 \%$. In this analysis, however, EUS has not been performed by one experienced examiner under standardized conditions in one specialized center, but unstandardized EUS reports have been collected from different hospitals and institutions. Together with the report of a French group (10), from our knowledge our cohort is the largest ever published worldwide referring to EUS findings with all patients examined by one experienced examiner following a standard protocol $(8,18,19)$. Both studies come to a comparable success rate of about $90 \%$ correct localization.

Still superior to all preoperative localization procedures is intraoperative ultrasound in combination with the palpation of the pancreas by an experienced surgeon $(14,20,21)$. For a long time, preoperative localization of insulinomas has therefore been considered interesting,

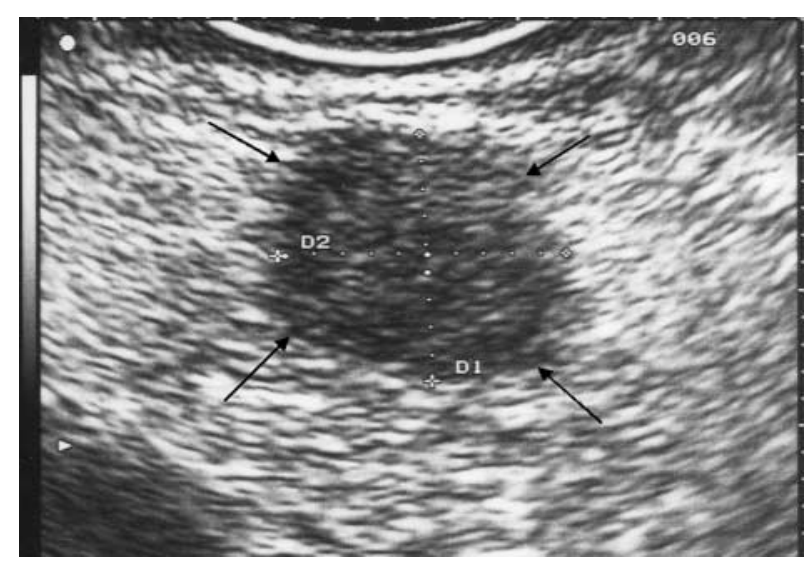

Figure 1 Preoperative endoscopic ultrasound of a typical hypoechoic insulinoma in a 67-year-old female. 


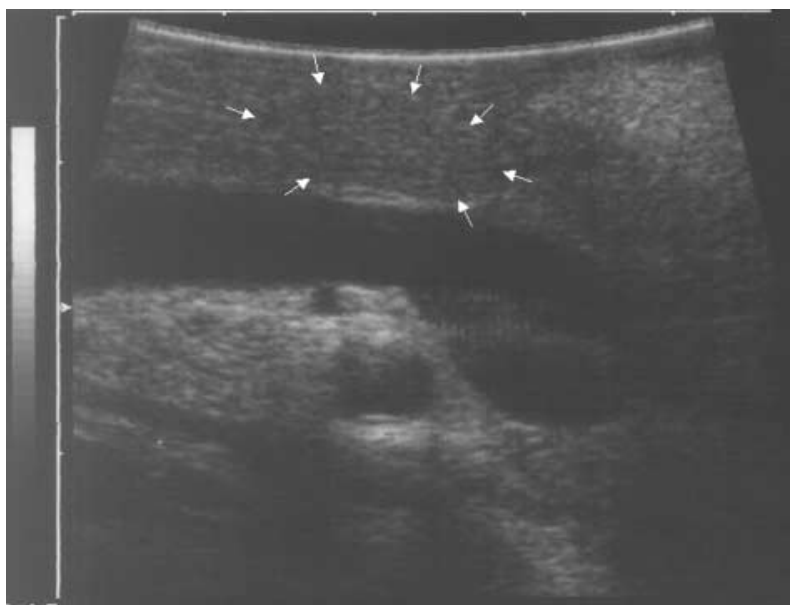

Figure 2 Intraoperative ultrasound of an isoechoic insulinoma in a 29-year-old female. The tumor could only be demonstrated after bimanual palpation of the pancreas.

however, not mandatory in cases of primary conventional surgery in patients without multiple endocrine neoplasia (14). Patients underwent surgical treatment if diagnosis had been established by endocrine testing. Recently, however, minimal invasive surgery has been established as an alternative to treat insulinoma patients (9). In this case, preoperative EUS of insulinomas is important to show the localization of the tumor and its relation to critical structures in the neighborhood (vessels, bile and pancreatic duct), to provide criteria for malignancy and clarify whether this is a uni- or multilocular disease $(18,22)$. Therefore, EUS enables identification of patients that qualify for laparoscopic, minimal invasive surgery (7-9).

As we learned and as others did, some insulinomas are missed by EUS imaging $(8,19)$. This may always be due to technical problems or poor performance of the examiner. An additional problem seems to be the correct position of the patient during EUS imaging. The transducer might slip over the pancreas to a more lateral position when the patient is lying on the left side as

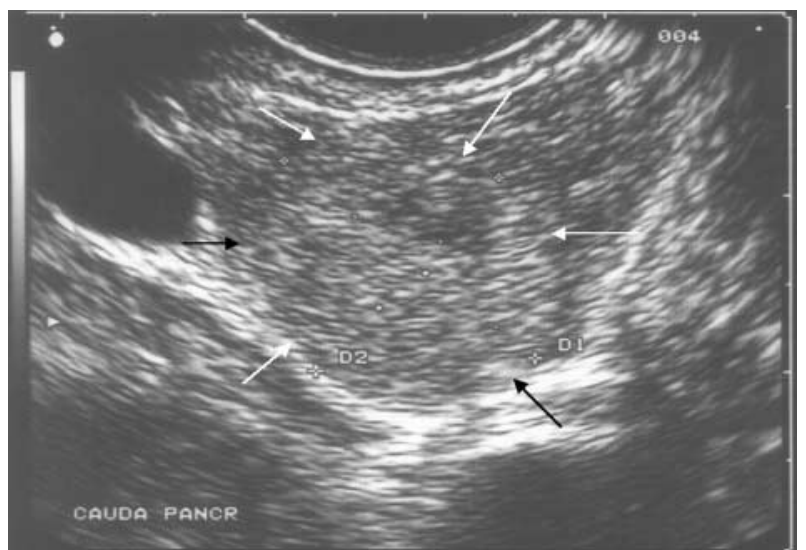

Figure 3 Preoperative endoscopic ultrasound of a hyperechoic insulinoma in a 29 -year-old female.

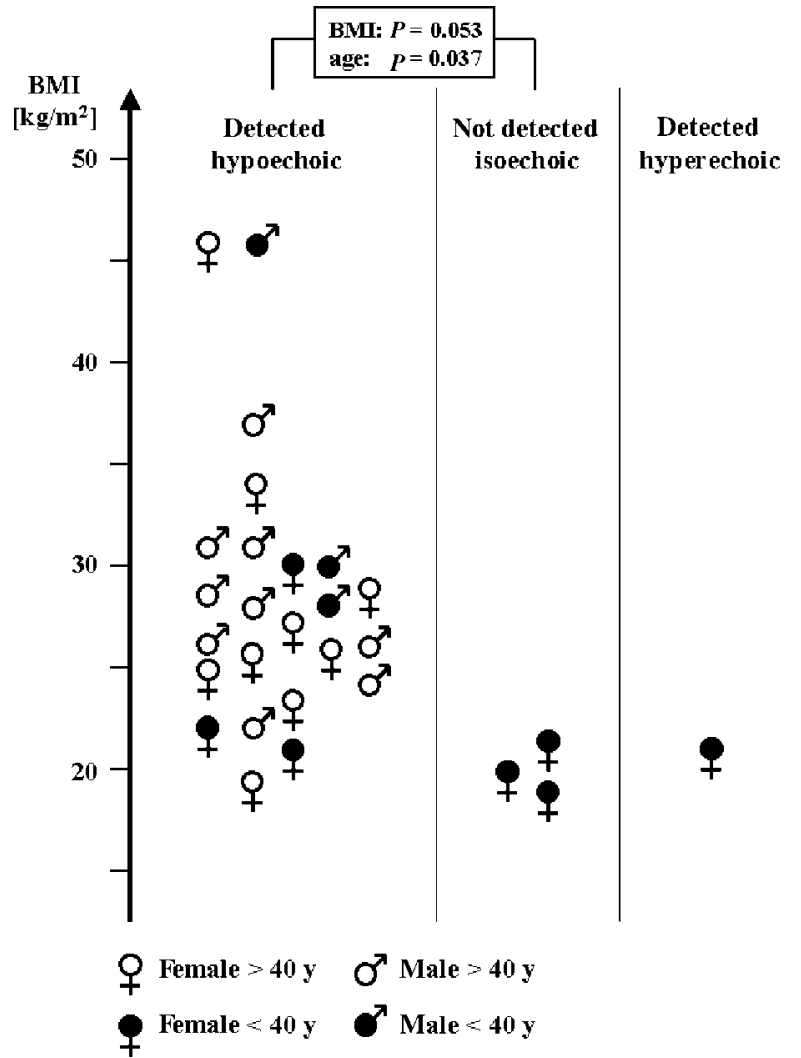

Figure 4 BMI of patient group 1 (detected hypoechoic); group 2 (not detected isoechoic) and group 3 (detected hyperechoic); age and gender indicated by symbols (in one patient the BMI was not available).

practiced in numerous centers. Our clinical experience shows that after negative EUS elsewhere, repeated imaging may become positive when the patient is in supine position (8). However, also 'intrinsic factors' of the patient may contribute. After experience with completely isoechoic insulinomas which could hardly be demonstrated following palpation of the pancreas intraoperatively (Fig. 2), this retrospective study including all EUS examinations of sporadic insulinomas performed by one single experienced examiner over a period of one decade was aimed to identify factors associated with negative EUS imaging. The insulinomas missed by preoperative EUS were at positions 18, 23, and 24 on the examiner's learning curve. Therefore, it seems unlikely that poor experience contributed to the unsuccessful localization. Low body mass index and young age were associated with negative EUS imaging, and all patients with negative imaging were females. This may be explained by the weak contrast of the tumor to healthy pancreatic tissue which in slim young females is often found to be more hypoechoic than usual due to low fat content.

The diameter of insulinoma had no influence on the success of EUS imaging. This is not surprising as the resolution of this imaging method allows even the detection of small pancreatic tumors with a tumor size down to $2-3 \mathrm{~mm}(8,22)$. The location of insulinoma had 
no influence either as in our clinical experience investigation of the whole pancreas including the tail is possible, while the patient remains in the above described position. It was not the size or location, but the complete isoechogeneity of the tumor which was the limiting factor in the three patients in whom the tumor could not be detected preoperatively.

Finally, there were no differences between the patient groups concerning endocrine parameters (insulin concentrations and insulin-glucose ratios) obtained during the prolonged fasting test. However, it has to be mentioned that these data were quite heterogeneous. Because of the rarity of insulinomas and retrospective analysis of data over almost one decade, fasting tests were performed at different institutions and neither test protocols nor measurement of glucose and insulin concentrations were standardized in this study. Insulin concentrations were mainly determined by RIA, but in at least eight of the patients included in this study by a specific immunochemiluminometric assay. Because insulinomas may secrete high concentrations of proinsulin, insulin concentrations measured by specific immunoassays are lower than insulin levels obtained by traditional RIAs exhibiting considerable cross-reactivity with proinsulin $(13,23,24)$. Insulin concentrations and insulinglucose ratios would probably have been greater in these patients if an RIA had been performed, complicating the comparison of the data.

In conclusion, some insulinomas are missed by preoperative EUS imaging as they are completely isoechoic. A low body mass index, female gender, and young age might be risk factors for negative imaging. This may be explained by weak contrast of the tumor to healthy pancreatic tissue which in slim young females is often found to be more hypoechoic than usual due to low fat content.

\section{References}

1 Service FJ. Hypoglycemic disorders. New England Journal of Medicine $19953321144-1152$.

2 Service FJ \& Natt N. The prolonged fast. Journal of Clinical Endocrinology and Metabolism 200085 3973-3974.

3 Service FJ. Diagnostic approach to adults with hypoglycemic disorders. Endocrinology and Metabolism Clinics of North America 199928 519-532.

4 Zimmer T, Scherubl H, Faiss S, Stolzel U, Riecken EO \& Wiedenmann B. Endoscopic ultrasonography of neuroendocrine tumours. Digestion 200062 45-50.

5 Ardengh JC, Rosenbaum P, Ganc AJ, Goldenberg A, Lobo EJ, Malheiros CA, Rahal F \& Ferrari AP. Role of EUS in the preoperative localization of insulinomas compared with spiral CT. Gastrointestinal Endoscopy 200051 552-555.

6 Besim H, Korkmaz A, Hamamcy O \& Karaahmetoglu S. Review of eight cases of insulinoma. East African Medical Journal 200279 368-372.

7 Fendrich V, Bartsch DK, Langer P, Zielke A \& Rothmund M. Diagnosis and surgical treatment of insulinoma - experiences in 40 cases. Deutsche Medizinische Wochenschrift 2004129 941-946.
8 Kann PH, Rothmund M \& Zielke A. Endoscopic ultrasound imaging of insulinomas: limitations and clinical relevance. Experimental and Clinical Endocrinology and Diabetes 2005113 471-474.

9 Langer P, Bartsch DK, Fendrich V, Kann PH, Rothmund M \& Zielke A. Minimal-invasive operative treatment of organic hyperinsulinism. Deutsche Medizinische Wochenschrift 2005130514 518.

10 Mirallie E, Pattou F, Malvaux P, Filoche B, Godchaux JM, Maunoury V, Palazzo L, Lefebvre J, Huglo D, Paris JC, Carnaille B \& Proye C. Value of endoscopic ultrasonography and somatostatin receptor scintigraphy in the preoperative localization of insulinomas and gastrinomas. Experience of 54 cases. Gastroenterologie Clinique et Biologique 200226 360-366.

11 Wiesli P, Brandle M, Schwegler B, Lehmann R, Spinas GA \& Schmid C. A plasma glucose concentration below $2.5 \mathrm{mmol} / \mathrm{L}$ is not an appropriate criterion to end the 72-h fast. Journal of Internal Medicine 2002252 504-509.

12 Kann PH \& Schaefer S. Clinic and diagnostic of insulinoma. In Endocrine Surgery. Ed M Rothmund. Heidelberg, Berlin, New York, Tokyo: Springer Verlag, 2007.

13 Hirshberg B, Livi A, Bartlett DL, Libutti SK, Alexander HR, Doppman JL, Skarulis MC \& Gorden P. Forty-eight-hour fast: the diagnostic test for insulinoma. Journal of Clinical Endocrinology and Metabolism 200085 3222-3226.

14 Böttger T, Junginger T, Beyer J \& Düber C. Is preoperative site diagnosis in organic hyperinsulinism from the viewpoint of the surgeon still necessary today? Results of a consecutive series and analysis of the literature. Die Chirurg 199667 268-272.

15 Anderson MA, Carpenter S, Thompson NW, Nostrant TT, Elta GH \& Scheiman JM. Endoscopic ultrasound is highly accurate and directs management in patients with neuroendocrine tumors of the pancreas. American Journal of Gastroenterology 200095 2271-2277.

16 McLean AM \& Fairclough PD. Endoscopic ultrasound in the localisation of pancreatic islet cell tumours. Best Practice and Research Clinical Endocrinology and Metabolism 200519 177-193.

17 Nesje LB, Varhaug JE, Husebye ES \& Odegaard S. Endoscopic ultrasonography for preoperative diagnosis and localization of insulinomas. Scandinavian Journal of Gastroenterology 200237732 737.

18 Kann P, Bittinger F, Engelbach M, Bohner S, Weis A \& Beyer J. Endosonography of insulin-secreting and clinically non-functioning neuroendocrine tumors of the pancreas: criteria for benignancy and malignancy. European Journal of Medical Research 20016 385-390.

19 Kann PH, Wirkus B, Keth A \& Goitom K. Pitfalls in endosonographic imaging of suspected insulinomas: pancreatic nodules of unknown dignity. European Journal of Endocrinology 2003148 531534.

20 Rothmund M, Rückert K \& Beyer J. Insulinomas and rare endocrine tumors. Die Chirurg 198657 541-551.

21 Brown CK, Bartlett DL, Doppman JL, Gorden P, Libutti SK, Fraker DL, Shawker TH, Skarulis MC \& Alexander HR. Intraarterial calcium stimulation and intraoperative ultrasonography in the localization and resection of insulinomas. Surgery $1997 \mathbf{1 2 2} 1189$ 1194.

22 Langer P, Kann PH, Fendrich V, Richter G, Diehl S, Rothmund M \& Bartsch DK. Prospective evaluation of imaging procedures for the detection of pancreaticoduodenal endocrine tumors in patients with multiple endocrine neoplasia type 1. World Journal of Surgery 2004 28 1317-1322.

23 Gorden P, Skarulis MC, Roach P, Comi RJ, Fraker DL, Norton JA, Alexander HR \& Doppman JL. Plasma proinsulin-like component in insulinoma: a 25-year experience. Journal of Clinical Endocrinology and Metabolism 199580 2884-2887.

24 Wiesli P, Brandle M, Zapf J, Seiler H, Zwimpfer C, Spinas GA \& Schmid C. Assessment of hyperinsulinaemia at the termination of the prolonged fast. Clinica Chimica Acta 2004342 227-231.

Received 22 February 2007

Accepted 3 May 2007 